\title{
Microplastics, microfibres and nanoplastics cause variable sub-lethal responses in mussels (Mytilus spp.)
}

Matthew Cole ${ }^{1,2 \#}$, Corin Liddle ${ }^{1}$, Giulia Consolandi ${ }^{1,3 \#}$, Claudia Drago ${ }^{1,4 \#}$, Cameron Hird ${ }^{1}$, Penelope K. Lindeque ${ }^{2} \&$ Tamara S. Galloway ${ }^{1}$

${ }^{1}$ College of Life and Environmental Sciences: Biosciences, University of Exeter, Exeter EX4 4QD, United Kingdom

${ }^{2}$ Marine Ecology and Biodiversity Group, Plymouth Marine Laboratory, Plymouth PL1 3DH, United Kingdom

${ }^{3}$ School of Environment, Geography and Geoscience, University of Portsmouth, Portsmouth PO1 3QL, United Kingdom

${ }^{4}$ Department of Ecology and Ecosystem Modelling, University of Potsdam, Am Neuen Palais 10, 14469 Potsdam, Germany

\# indicates current research institute

* Corresponding author: MC: Phone: +44(0)1752 633100; e-mail: mcol@pml.ac.uk.

\section{Abstract}

We compare the toxicity of microplastics, microfibres and nanoplastics on mussels. Mussels (Mytilus spp.) were exposed to $500 \mathrm{ng} \mathrm{mL}-1$ of $20 \mu \mathrm{m}$ polystyrene microplastics, $10 \times 30 \mu \mathrm{m}$ polyamide microfibres or $50 \mathrm{~nm}$ polystyrene nanoplastics for $24 \mathrm{~h}$ or 7 days. Biomarkers of immune response, oxidative stress response, lysosomal destabilisation and genotoxic damage were measured in haemolymph, digestive gland and gills. Microplastics and microfibres were observed in the digestive glands, with significantly higher plastic concentrations after 7-days exposure (ANOVA, $P<0.05$ ). Nanoplastics had a significant effect on hyalinocyte-granulocyte ratios (ANOVA, $P<0.05$ ), indicative of a heightened immune response. SOD activity was significantly increased followed $24 \mathrm{~h}$ exposure to plastics (two-way ANOVA, $\mathrm{P}<0.05$ ), but returned to normal levels after 7 -days exposure. No evidence of lysosomal destabilisation or genotoxic damage was observed from any form of plastic. The study highlights how particle size is a key factor in plastic particulate toxicity. 


\section{Graphical abstract}

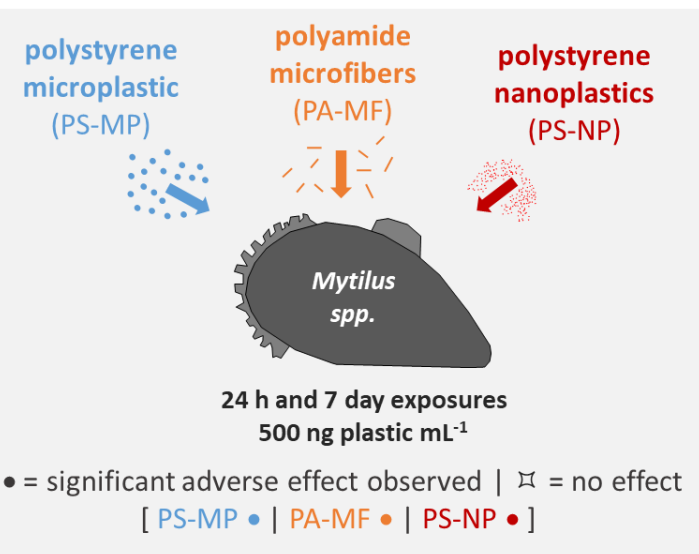

Immune response:

- Granulocyte-hyalinocyte [ $24 \mathrm{~h} \bullet \mid 7 \mathrm{~d} \bullet$ ]

Oxidative stress response:

- $\operatorname{SOD}[24 \mathrm{~h} \bullet \bullet / 7 \mathrm{~d} \square]$

- TBARS [ $24 \mathrm{~h} \pi \mid 7 \mathrm{~d} \Xi]$

Lysosomal destabilisation:

- Neutral red retention $\square$

Genotoxic damage:

- Micronucleus assay $\square$

- Comet assay $\square$

\section{Keywords}

Plastic; litter; debris; pollution; shellfish; bivalve; fibres; exposure; ecotoxicology

\section{Highlights}

- Mussels (Mytilus edulis) exposed to micro- and nanoplastics for $24 \mathrm{~h}$ and 7 days.

- Microplastics and microfibres aggregated in the digestive glands.

- Plastic exposure caused a short-lived increase in SOD activity.

- Nanoplastics triggered an innate immune response.

\section{INTRODUCTION}

Plastic debris is a prolific and persistent marine contaminant that has permeated throughout the global ocean. Microplastic $(0.1 \mu \mathrm{m}-1 \mathrm{~mm})$ and nanoplastic $(<0.1 \mu \mathrm{m})$ debris (Hartmann et al., 2019) may pose a substantial risk to marine ecosystems (Galloway et al., 2017). Micro- and nanoscopic plastics can be directly manufactured (e.g. medical applications, personal care products), or derive from the physico-chemical degradation of plastic debris. Plastic can enter into marine ecosystems through a myriad of pathways including direct disposal, airborne dispersal, terrestrial run-off and riverine flow (Cole et al., 2011). Microplastics and microfibres have been identified in seawater, sediments, polar ice and biota across the globe (Bergmann et al., 2016; Lusher, 2015), while recent methodological advances have allowed for the identification of waterborne nanoplastics in samples taken from the North Pacific gyre (Ter Halle et al., 2017).

Owing to their small size, micro- and nanoplastics are bioavailable to a wide array of aquatic organisms, with evidence of plastic particulates being directly or indirectly (i.e. via trophic transfer) 
consumed, or inhaled via the gills (Setälä et al., 2018). Microplastic debris has been identified in a wide range of marine organisms, with highest concentrations found in animals at the base of the marine food web (e.g. bivalve shellfish) (Walkinshaw et al., 2020). Microplastics have been shown to incite adverse health effects including reduced feeding, fecundity and premature moulting in copepods (Cole et al., 2019; Cole et al., 2015; Coppock et al., 2019), diminished reproductive outputs and offspring performance in Pacific oysters (Sussarellu et al., 2016), and reduced feeding, weight loss and reduced activity in benthic polychaetes (Besseling et al., 2013; Wright et al., 2013; Wright et al., 2015). Toxicological effects stemming from nanoplastic exposure include reduced feeding, body size and reproductive endpoints in Daphnia (Besseling et al., 2014; Rist et al., 2017), reduced fertilisation success and increases in larval abnormalities in Pacific oyster (Tallec et al., 2018), and heightened immune response, oxidative damage and inflammation in fish (Brandts et al., 2018b; Greven et al., 2016; Lu et al., 2016).

The blue mussel (Mytilus edulis) and Mediterranean mussel (Mytilus galloprovincialis) have been widely used in assessing the risks posed by environmental stressors (Farrington et al., 2016; Viarengo and Canesi, 1991). Mussels are omnivorous suspension feeders with proven capacity for consuming microplastics (Ward et al., 2019a). Numerous field-studies have demonstrated that mussels can readily consume microplastic debris under environmental conditions (De Witte et al., 2014; Li et al., 2018; Li et al., 2015; Rochman et al., 2015; Santana et al., 2016; Van Cauwenberghe and Janssen, 2014; Zhao et al., 2018). In mussels, waterborne particles are captured via the gills, with capture efficiency and ingestion dependent upon particle size, shape, hydrophobicity, and aggregation within biogenic matrices (e.g. marine snow) (Kach and Ward, 2008; Porter et al., 2018; Rosa et al., 2018; Ward and Targett, 1989; Ward and Shumway, 2004); particles are subsequently sorted via the labial palps (Beninger et al., 1995), and either ingested or ejected within pseudofaeces (Ward et al., 2019b; Zhao et al., 2018). Microplastics have been shown to aggregate in the gills and digestive glands (Avio et al., 2015; Browne et al., 2008; Paul-Pont et al., 2016; Pittura et al., 2018; Revel et al., 2019; von Moos et al., 2012) and adhere on organs not associated with feeding, including the adductor muscles, foot and mantle (Kolandhasamy et al., 2018); there is also some evidence that $<20 \mu \mathrm{m}$ microplastics can translocate into the haemolymph (Browne et al., 2008; von Moos et al., 2012). To date, toxicity studies considering the impacts of plastics on mussels (and may other organisms) have primarily considered the impact of high-doses of spherical microbeads or irregularly-shaped plastic fragments (Lenz et al., 2016); to the authors' knowledge only one other study has considered the impact of plastic fibres on mussels, in which microfibres were shown to significantly reduce filtration rates in M. edulis (Woods et al., 2018). 
This study sets-out to better understand the risks plastic particulates, varying in shape and size, pose to marine mussels, and highlight differences in the mechanisms of toxic action, caused by microplastics, microfibres and nanoplastics. Microfibres are among the most commonly observed forms of plastic debris in marine samples (Lindeque et al., 2020; Mishra et al., 2019), but are largely underrepresented in ecotoxicological studies on microplastics (Trestrail et al., 2020), and there are relatively few in vivo studies with nanoplastics. Here, acute ( $24 \mathrm{~h}$ and 7-day) exposure studies using the model organism $M$. edulis were undertaken to compare the effects polystyrene microplastics (spherical beads), polyamide microfibers and polystyrene nanoplastics (spherical beads) can have on mussel health. Biomarkers (indicators of an adverse health response) for immune response, oxidative balance, lysosomal destabilisation and genotoxic damage were selected as relevant endpoints, based on the findings of prior toxicological studies (Détrée and Gallardo-Escárate, 2018; Paul-Pont et al., 2016; Revel et al., 2019; von Moos et al., 2012). It was hypothesised that sub-lethal toxicity would vary with the size and shape of the plastic: (1) given their high-aspect ratio (i.e. particle length is far greater than particle width), it is proposed that microfibers will more readily aggregate and become lodged within the digestive tract than spherical microbeads, increasing their likelihood of causing sub-lethal harm $\left(\mathrm{H}_{1}\right)$; and (2) owing to their diminutive size, it was anticipated that nanoplastics will more readily penetrate into tissues and the haemolymph than microplastics and will therefore be more likely to trigger an immune response $\left(\mathrm{H}_{2}\right)$. The results of the study provide insight into the mechanisms by which plastic particulates can cause harm to mussels, contributing to our understanding of the risks plastic pollution poses to marine life.

\section{METHODS}

\section{Animal collection and husbandry}

Mussels (Mytilus spp.) were sampled from the established mussel population at Starcross (Stephenson and Thomas, 2019) in the Exe estuary (UK; 50 $37^{\prime} 26.22^{\prime \prime} N 32^{\circ} 6^{\prime} 45.24^{\prime \prime}$ W) at low-tide in late July 2016 and early August 2017. Mussels with shell length of $\sim 6 \mathrm{~cm}$ were hand-picked, placed in coolboxes containing natural seawater and returned to the laboratory within 1 hour of sampling. Fouling organisms (e.g. barnacles, algae) were removed from mussel shells using a scalpel. Mussels were depurated for $24 \mathrm{~h}$ in $0.2 \mu \mathrm{m}$ filtered, $33 \pm 0.3 \mathrm{ppt}$ artificial seawater (ASW), prepared using purified water and marine salts (Tropic Marin). Prior to experimental work, mussels were acclimated for between 7-14 days in recirculation tanks containing ASW. Mussels were fed daily by pausing the recirculation system for 2 hours, and providing $200 \mu \mathrm{L} \mathrm{L}^{-1}$ ASW (approximately $4 \times 10^{8}$ microalgae $\mathrm{L}^{-1}$ 
ASW) of Shellfish Diet $1800^{\circledR}$ (Reed Mariculture), a commercial formulation of microalgae, comprising Isochrysis sp., Pavlova sp., Tetraselmis sp., Chaetoceros calcitrans, Thalassiosira weissflogii and Thalassiosira pseudonana.

\section{Microplastics and nanoplastic preparation}

Test plastics were selected for their bioavailability to mussels. Polystyrene and polyamide particles have densities similar to that of seawater $\left(p=1.05 \mathrm{~g} \mathrm{~cm}^{-3}\right)$, and therefore could be expected to remain suspended within experimental beakers; ideally all plastics would have been manufactured from the same polymer, however polystyrene fibres could not be sourced. Particle size ranges overlap with that of the natural prey of mussels, with $50 \mathrm{~nm}$ nanoplastics used to represent particulates with capacity for permeating into tissues.

Polystyrene microplastics (PS-MP): Polystyrene monodisperse beads (20 $\mu \mathrm{m} \emptyset$; Sigma 87896) were selected as a representative plastic particulates, similar to those used in other toxiciology studies with mussels. To remove any preservatives (e.g. azides) present in the stock solution, we followed the protocol of Cole and Galloway (2015). In brief: stocks were transferred to a Falcon tube, centrifuged and the supernatant removed; the plastic pellet was then re-suspended in ultrapure water, with the process repeated a total of three times.

Polyamide microfibres (PA-MF): Nylon microfibres $(10 \varnothing \times 30 \mu \mathrm{m})$ were prepared by sectioning polyamide nylon 6,6 polyfilament fibre (Goodfellow AM325705) using a cryogenic microtome and fibre size verified using microscopy per the protocol of Cole (2016). Equivalent spherical diameter of microfibres were calculated as $19.2 \mu \mathrm{m}$, per the formulae prescribed by Malvern (2014).

Microplastics and microfibres were suspended in ultrapure water and kept in the dark at $2-4^{\circ} \mathrm{C}$ to prevent microbial growth. Microplastic stocks were vortexed for $\sim 10 \mathrm{~s}$ to resuspend plastics prior to use, and concentrations were quantified using a Sedgewick-rafter chamber. Microplastic mass (M) was calculated using the formula: $M=p \times V$, with their volume $(V)$ based on the volume of a sphere for microbeads and a cylinder for microfibers, and their density $(p)$ based on their polymer, i.e. $1.05 \mathrm{~g}$ $\mathrm{cm}^{-3}$ for polystyrene and $1.14 \mathrm{~g} \mathrm{~cm}^{-3}$ for nylon 6,6 , with $500 \mathrm{ng}$ particles $\mathrm{mL}^{-1}$ equivalent to 114 PS$\mathrm{MP} \mathrm{mL}^{-1}$ and $186 \mathrm{PA}-\mathrm{MF} \mathrm{mL}^{-1}$. 
Polystyrene nanoparticles (PS-NP): - Fluorescent polystyrene sulphated-nanobeads (50 nm ø; Ex. 505545, Em. 560-630; Magsphere, Pasadena, CA, USA) were supplied as suspensions (2.5\% w/v; azide free), which was stored at $4^{\circ} \mathrm{C}$ as per the manufacturer guidelines. Sulphated PS-NPs were chosen as the surface sulphate groups have been demonstrated to enhance their dispersion in seawater (Wegner et al., 2012) in the same way that eco-corona formation on nanoplastics can facilitate their dispersal under environmental conditions (Saavedra et al., 2019); the stability of the PS-NP was tested using dynamic light scattering (DLS), which confirmed good dispersion within seawater (Figure S1-S2). Particles were characterised with transmission electron microscopy (TEM) and DLS; test particles demonstrated a zeta potential of $-30.9 \pm 1.9 \mathrm{mV}$ and a measured hydrodynamic diameter (HDD) of $52.65 \pm 2.88 \mathrm{~nm}$ (DLS), and mean particle size was $34 \pm 8.6 \mathrm{~nm}$ (TEM); further characteristics are provided in Table S1. For dosing the test systems, a stock of $1000 \mathrm{mg} / \mathrm{L}$ was used, with $500 \mathrm{ng} \mathrm{mL}^{-1}$ equivalent to $7.3 \times 10^{9} \mathrm{PS}-\mathrm{NP} \mathrm{mL}^{-1}$.

\section{Experimental set-up (Exposure 1 and Exposure 2)}

The study comprised two complimentary experimental set-ups: Exposure 1 was conducted in August 2016 using cohorts of 6 mussels (allowing for pooling of tissues and haemolymph prior to conducting bio-assays) exposed for either $24 \mathrm{~h}$ ( $\mathrm{n}=4$ per treatment) or 7 days ( $\mathrm{n}=4$ per treatment) in $5 \mathrm{~L} \mathrm{ASW}$; Exposure 2 was conducted in August 2017, using individual mussels (allowing for greater replication) exposed for 7 days only ( $\mathrm{n}=8$ per treatment) in $1 \mathrm{~L} \mathrm{ASW}$. Mussels (average \pm se: $5.93 \pm 0.02 \mathrm{~cm}$; range: 5.06-6.92 cm) were placed carefully at the base of acid-washed glass beakers and then ASW carefully poured in. Filtered air was pumped in via a glass pipette to provide aeration and keep the water sufficiently agitated to maintain particulate dispersion; beakers were covered with cling-film to prevent airborne contamination and evaporative loss. Plastics were added to each beaker via micropipette, with treatments comprising controls (no plastic), or $500 \mathrm{ng} \mathrm{mL}^{-1}$ of either PS-MP, PA-MF or PS-NP, chosen with reference to Lenz et al (2016) and other ecotoxicological studies (see references in results and discussion). Beakers were randomly allocated (Microsoft Excel) a position on a tray within a controlled-temperature room $\left(15^{\circ} \mathrm{C} ; 12 \mathrm{~h}: 12 \mathrm{~h}\right.$ light:dark) and maintained for either $24 \mathrm{~h}$ or 7 days. For the 7-day exposure, mussels were fed daily with $200 \mu \mathrm{L} \mathrm{L}^{-1} \mathrm{ASW}$ of Shellfish Diet $1800^{\circledR}$ (Reed Mariculture); $1 \mathrm{~h}$ after feeding, a complete water change was undertaken, and plastics added. Mussels were observed prior to feeding, after feeding and after dosing with plastics, recording whether they were feeding or not (i.e. valves open, mantle visible, particles visibly drawn into the mussel).

\section{Haemolymph and tissue sampling}


At the end of each exposure, mussels were removed from experimental vessels, opened-up using sterile, stainless-steel scissors and excess seawater removed (i.e. gently blotting with blue roll). Haemolymph was extracted from the posterior adductor muscle using a hypodermic syringe preloaded with $100 \mu \mathrm{L}$ of cold phosphate buffered saline (PBS); in Exposure 1 haemolymph was pooled and in Exposure 2 haemolymph was collected from a single mussel. The digestive gland and gills were excised using sterile stainless-steel forceps and/or scissors. Haemolymph and tissues were blotted on blue roll, and then placed in Eppendorfs with 50\% PBS and either analysed immediately, or snapfrozen in liquid nitrogen and stored at $-80^{\circ} \mathrm{C}$ prior to analysis.

\section{Uptake of microplastics and nanoplastic (Exposure 1)}

To confirm dietary uptake and assess the accumulation of microplastics in the digestive glands (Exposure 1: $24 h, n=4 ; 7$ days, $n=4$ ), the glands were excised, patted dry, weighed (mg, wet-weight), and then digested for $\sim 16$ hours in a drying oven $\left(50^{\circ} \mathrm{C}\right)$ using $2 \mathrm{~mL}$ of $10 \% \mathrm{KOH}$ per $\mathrm{mg}$ of tissue. Microplastics were quantified using a light microscope (x20 objective), and the concentration of microplastics per mg of digestive gland (wet-weight) calculated.

To demonstrate the uptake of PS-NP into the mussel tissues (Exposure 1: $24 h, n=4 ; 7$ days, $n=4$ ), the tissues was homogenised with a probe sonicator in $2 \mathrm{~mL}$ of ultrapure water. The fluorescence dye was then extracted from the tissue by adding $2 \mathrm{~mL}$ of 2-ethoyethyl acetate solvent and agitated on a shaker-plate for $24 \mathrm{~h}$. The phases were then separated via centrifugation (2000 g) for $10 \mathrm{~min}$ and the supernatant containing the dye was measured using a spectro-fluorometer (Biotek Synergy HT) (Hussain, 2001; Ravnic et al., 2006).

\section{Immune response: Granulocyte-hyalinocyte ratio (Exposure 1)}

The proportion of granulocytes (phagocytic haemocytes) and hyalinocytes (agranular haemocytes that do not display a phagocytic response) present in mussel haemolymph was used as a biomarker of immunological response. Per the protocol of Gorbi et al. (2013) and Avio et al. (2015), haemolymph was spread onto a glass slide, air-dried and fixed with Beker's fixative with $2.5 \% \mathrm{NaCl}$, and then washed and stained with 3\% May-Grünwald Giemsa. Slides were visualised under a light microscope (x10 objective), and 200 cells classified.

\section{Oxidative balance: SOD and TBARS (Exposure 1)}

The SOD assay provides a measure of antioxidant enzyme levels in tissues, with 1 unit of SOD per mg $\left(\mathrm{U} \mathrm{mg}^{-1}\right)$ corresponding to a $50 \%$ reduction of nitroblue tetrazolium (NBT). SOD activation in gills and 
digestive gland tissues were determined by measuring their ability to inhibit the generation of NBT, as described in Noventa et al. (2018). Briefly, digestive gland and gill tissues were rinsed with phosphate buffered saline, then homogenized on ice and superoxide radicals generated by adding xanthinexanthine oxidase. Absorbance values were determined at $573 \mathrm{~nm}$ for $10 \mathrm{~min}$ via spectrophotometer. Absorbance values were compared to a standard curve, plotting inhibition of NBT generation against SOD concentrations $\left(0-20 \mathrm{U} / \mathrm{mL} ; R^{2}=0.99\right)$, and accounting for the mean protein content of the tissues (Bradford, 1976).

TBARS concentrations in gill and digestive gland tissues were measured using the method of Buege and Aust (1978), adapted to a micro plate reader (Biotek Synergy HT; absorbance: $530 \mathrm{~nm}$ ). In brief: $150 \mu \mathrm{L}$ of samples was heated at $60^{\circ} \mathrm{C}$ for $60 \mathrm{~min}$ in a solution containing $50 \%$ trichloroacetic acid, $1 \%$ butylated hydroxytoluene, $1 \mathrm{mM}$ phosphate-buffered saline and ethylenediaminetetraacetic acid, and $1.3 \%$ thiobarbituric acid (TBA) in $0.3 \% \mathrm{NaOH}$. The tubes were then cooled, and after mixing, the TBARS level was quantified at $530 \mathrm{~nm}$ by using a micro plate-reading UV-spectrophotometer (Biotek Synergy $H T)$. Results were expressed in $n M$ of TBARS per mg of protein. TBARS production $\left(n M m^{-1}\right.$ ) was ascertained by comparing the lipid peroxidation activity of tetramethoxypropane standards $\left(R^{2}=1.00\right)$, accounting for the mean protein content of the tissues (Bradford, 1976).

\section{Lysosomal destabilisation: Neutral red retention (Exposure 2)}

The neutral red retention assay provides a quantitative estimation of oxidative damage in cells (Repetto et al., 2008). Healthy cells can rapidly incorporate and store neutral red dye in their lysosomes, while damaged cells are unable to retain the dye; as such, the neutral red retention can be used as a measure of the health of cell populations. Per the protocol of Hu et al. (2015), $100 \mu \mathrm{L}$ aliquots of fresh haemolymph-PBS solution (50\% dilution) were pipetted in triplicate into a 96 -well plate (Greiner), with $100 \mu \mathrm{L}$ of PBS used for blanks. The microplate was incubated on a shaker plate at room temperature for $20 \mathrm{~min}$ to facilitate cell adhesion, and then the plate inverted and excess haemolymph/PBS carefully removed. Next, $50 \mu \mathrm{L}$ of $200 \mu \mathrm{M}$ neutral red-PBS solution was added to each well, plates incubated for 15 minutes in the dark and then excess neutral red dye carefully removed. Adhered cells were washed and fixed with $150 \mu \mathrm{L}$ of $1 \%$ glutaraldehyde for $2 \mathrm{~min}$, and then fixative removed. Finally, $200 \mu \mathrm{L}$ of extraction buffer (1\% acetic acid and $50 \%$ ethanol) was added to each well, and plates left in the dark for $20 \mathrm{~min}$ at room temperature. To allow for calibration of absorbance data, neutral red dye standards $\left(0-30 \mathrm{ng} \mathrm{mL}^{-1}\right)$ were prepared and $200 \mu \mathrm{L}$ pipetted into each plate prior to analysis. Absorbance of neutral red dye was ascertained using a microplate reader (TECAN, Infinite ${ }^{\circledR} 200$ PRO) at a wavelength of $540 \mathrm{~nm}$. 


\section{Genotoxicity: Micronucleus assay (Exposure 1) and comet assay (Exposure 2)}

The micronucleus test was used to quantify micronuclei formation in mussel haemocytes as a biomarker for genotoxicity. Adapting the protocol described by Avio et al. (2015), haemocytes were fixed in Carnoy's solution (3:1 methanol:acetic acid) and then spread onto glass slides, air dried and stained with SYBRsafe (0.5X, $45 \mathrm{mM}$ Tris-borate, $1 \mathrm{mM}$ EDTA, pH 8.3). Slides were visualised with an optical fluorescence microscope (Axiovert S100; x40 objective, oil immersion), and the number of micronuclei (smaller than one-third of nucleus diameter and on same optical plane) present across 1000 cells recorded.

DNA damage was evaluated using the alkaline version of the single cell gel electrophoresis assay (i.e. comet assay), following the protocol of Lewis and Galloway (2009). The Comet assay can be used to assess induced genetic damage, both as a direct and indirect impact of a contaminant, through identifying single-strand DNA breakages in individual cells (Jha, 2008). In brief: the haemolymph of each mussel was centrifuged at $1000 \mathrm{rpm}$ for 3 minutes at $4^{\circ} \mathrm{C}$ and the supernatant discarded. The pellets with the isolated cells were resuspended in low melting point agarose containing $1 \%$ Kenny's salt solution and spread onto microscope slides pre-coated with high melting point agarose with $1 \%$ Tris-acetate EDTA. The embedded cells were lysed by immersion in a cold lysis buffer $(2.5 \mathrm{M} \mathrm{NaCl}, 10$ mM Tris, 0.1 mM EDTA, 10\% DMSO, 1\% Triton X-100, pH 10, in dark conditions at $4^{\circ} \mathrm{C}$ ) for 1 hour. The slides were placed in a horizontal electrophoresis unit and incubated in an alkaline electrophoresis solution ( $300 \mathrm{mM} \mathrm{NaOH}, 1 \mathrm{mM}$ EDTA, deionized water, $\mathrm{pH}>13$, in dark conditions at $4^{\circ} \mathrm{C}$ ) for 40 minutes. Electrophoresis was conducted for 30 minutes at $25 \mathrm{~V}, 300 \mathrm{~mA}$. One slide with two gels was prepared per mussel, coloured with SYBRsafe Green (0.5X, 45Mm Tris-borate, $1 \mathrm{Mm}$ EDTA, pH 8.3) and observed with an optical fluorescence microscope (Axiovert S100, x20 objective with 420-490nm excitation and $520 \mathrm{~nm}$ emission filters) coupled with a digital camera (Sony). An image analysis programme (Komet 5.5, Kinetic Imaging Ltd) was used to analyse the comet images. For each gel, 50 nuclei were analysed blindly of treatment, making a total of 100 cells examined in each slide. \% Tail DNA was used to grade DNA damage.

\section{Statistical analysis}

Data was tabulated, and figures prepared using Microsoft Excel. Statistical analyses were undertaken using $R$ ( $R, 2019)$. Data was tested for normality using a Shapiro-Wilk test, transformed where applicable, and homogeneity of variance was visually inspected to satisfy apriori parametric requisites. An ANOVA with post hoc Tukey tests were used to compare parametric data, and a Kruskal-Wallis with post hoc Wilcox test used to compare non-parametric data; post-hoc analysis was used to compare 
data with the controls. A binomial General Linear Model (GLM) was used to compare DNA damage (Comet tail \%). Data is presented as mean \pm standard error, with statistical significance assigned to $P<0.05$. For comparisons of SOD and TBARS data by exposure length ( $24 \mathrm{~h}$ and 7 -day) the data was normalised to the control for the respective experiment to prevent a shift in the baseline of the experiment creating false positives, using the formula: (sample concentration / average (sample concentration)) * 100, where 'sample concentration' refers to the measured value of substance within the sample, and 'average (sample concentration)' refers to the mean value of the replicates within the sample; two-way ANOVAS were then conducted on the percentage data with Tukey post-hoc analysis.

\section{RESULTS AND DISCUSSION}

\section{Microplastic and nanoplastic uptake}

Mussels were observed to be actively feeding following addition of microalgae and exposure to PSMP, PA-MF and PS-NP. Food ingested by mussels is physically homogenised by the rotating crystalline style, digested extracellularly in the stomach, and then shunted into the digestive gland to undergo intracellular digestion (Gosling, 2003; Koukouzika et al., 2009); the glands comprise terminal epithelial tubules, with undigested food returned to the stomach prior to egestion, and as such may be considered a "dead-end" in which particulates might be retained (Faggio et al., 2018). Both PS-MP and PA-MF were identified in the digestive glands of mussels, with a significantly greater amount of microplastics identified in digestive glands following the 7-day exposure (two-way ANOVA, Time: $\mathrm{P}<0.05$; Figure 1). Our results demonstrate microfibres aggregate in the digestive gland of mussels, corroborating the findings of experimental studies using PS-MP $(2-16 \mu \mathrm{m})$, and irregularly-shaped, high-density polyethylene (HDPE, $<80 \mu \mathrm{m}$ ), low-density polyethylene (LDPE, 20-25 $\mu \mathrm{m}$ ), polyethylene and polystyrene $(<100 \mu \mathrm{m})$, and a polyethylene-polypropylene mix $(<720 \mu \mathrm{m})$ (Avio et al., 2015; Browne et al., 2008; Paul-Pont et al., 2016; Pittura et al., 2018; Revel et al., 2019; von Moos et al., 2012).

We observed no significant difference in the concentrations of PS-MP and PA-MF in the digestive glands after either $24 \mathrm{~h}$ or 7-days exposure (two-way ANOVA, Treatment: $\mathrm{P}=0.57$ ): PS-MP concentrations averaged $5.3 \pm 2.4$ microplastics $\mathrm{mg}^{-1}$ after $24 \mathrm{~h}$ exposure and $34.0 \pm 15.5$ microplastics $\mathrm{mg}^{-1}$ following the 7-day exposure (Tukey, Time: $\mathrm{P}=0.30$ ), while PA-MF concentrations averaged 10.0 \pm 8.7 microplastics $\mathrm{mg}^{-1}$ after $24 \mathrm{~h}$ exposure and $22.0 \pm 6.4$ microplastics $\mathrm{mg}^{-1}$ following the 7 -day exposure (Tukey, Time: $\mathrm{P}=0.28$ ). Based on this data, we conclude microfibres do not aggregate to any 
greater extent than spherical microbeads. As we explore below, there was also no difference in the levels of sub-lethal toxicity caused by $500 \mathrm{ng}$ particles $\mathrm{mL}^{-1}$ of microfibres and microplastic. In combination, these results lead us to reject hypothesis $\mathrm{H}_{1}$. Conversely, Gray and Weinstein (2017) identified that polypropylene microfibres $\left(50 \times 10^{6}\right.$ particles $\left.\mathrm{mL}^{-1}\right)$ resulted in significantly greater mortality in adult daggerblade grass shrimp when compared with exposure to microplastic beads and granules; further, Au et al. (2015) demonstrated that polypropylene microfibres cause mortality in the amphipod Hyalella azteca at far lower concentrations than polyethylene microplastic particles. Further experimental work using microfibres of varying length and aspect ratio are recommended to explore differences in toxicity.

Efforts to quantify PS-NP within mussel tissues was unsuccessful, as we were unable to distinguish the red fluorescence signal of the particles from autofluorescence. However, we remain confident that uptake occurred given our observations of active feeding, and evidence from other research papers that PS-NP (either free-floating or aggregated with microalgae) can be filtered-out by mussels; in these studies, PS-NP uptake was ascertained by measuring reduction of nanoparticle concentrations in the surrounding water and/or visualising uptake of PS-NP within tissues via fluorescence imaging (Brandts et al., 2018a; Sendra et al., 2019; Wegner et al., 2012), although such imaging studies have been criticised as leaching of fluorophores may give false positives (Catarino et al., 2019).

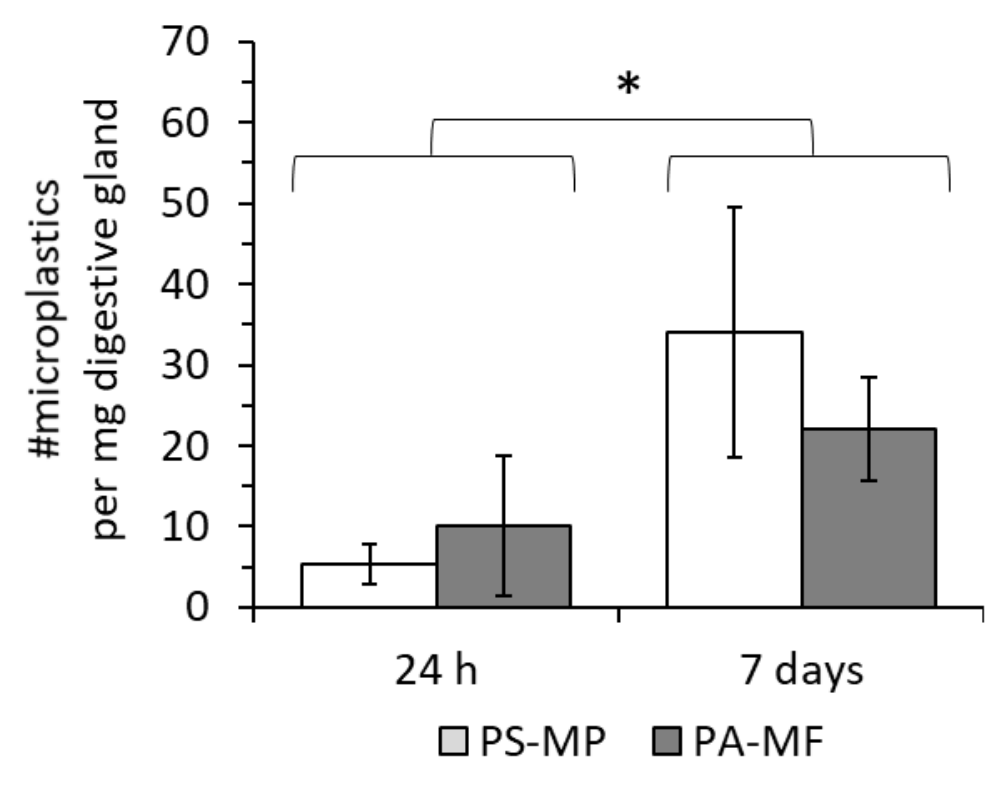

Figure 1. The number of polystyrene microbeads (PS-MP; $n=3$ ) and nylon microfibres (PA-MF; $n=4$ ) identified per mg of digestive gland tissue of individual mussels, following $24 \mathrm{~h}$ or 7 -day exposure to $500 \mathrm{ng} \mathrm{mL}^{-1}$ microplastics. * denotes statistical difference between microplastic concentrations in digestive glands of mussels following $24 \mathrm{~h}$ and 7 -day exposures (two-way ANOVA, Time: $\mathrm{P}<0.05$ ). 


\section{Immune response: Granulocyte-hyalinocyte ratio}

Haemocytes comprise spherical, eosinophilic 'granulocytes', containing hydrolytic enzymes, that play an active role in phagocytosis, and basophilic 'hyalinocytes' (Lowe and Moore, 1979); as such, an increase in the proportion of granulocytes present in the haemolymph is indicative of a heightened immune response. Our data shows the haemocyte ratio was significantly different between treatments for the $24 \mathrm{~h}$ and the 7-day exposures (two-way ANOVA, Treatment: $\mathrm{P}<0.05$; Figure 2), with a significant increase in the granulocyte-hyalinocyte ratio of mussels exposed to PS-NP (Tukey: $P<0.05$ (24 h); $\mathrm{P}<0.01$ (7-day)). There was no difference in haemolymph profiles after $24 \mathrm{~h}$ and 7-day exposures (two way-ANOVA, Time: $\mathrm{P}=0.18$ ). We recommend that chronic exposures could be designed to elucidate whether this immune response is sustained longer-term, following both continued plastic exposure and after mussels are depurated and kept in clean water.

The significant increase in the proportion of phagocytic haemocytes observed in the PS-NP treatments may have resulted from the $50 \mathrm{~nm}$ diameter nanoparticles translocating from the intestinal tract into the mussel's haemolymph triggering the innate immune response and a proliferation of the granulocytes, or localised inflammation resulting in granulocytic proliferation. In our previous studies with oysters, nanoparticles were taken up across the bivalve gut epithelium through an endocytic pathway and could be identified within the lysosomes and phagocytic cells (Noventa et al., 2018). Nanoparticles engulfed by phagocytes have been shown to trigger autophagy, fuse with lysosomes (potentially affecting lysosomal stability as the polymers are resistant to the hydrolytic processes) and cause toxicity through reactive oxygen species (ROS) formation, mitochondrial damage and localised inflammation; ultimately nanoparticles tend to accumulate in excretory organs (Gustafson et al., 2015).

In contrast to PS-NPs, exposure to PS-MP and PA-MF resulted in a non-significant increase in granulocyte-hyalinocyte ratio after 7-days exposure (Figure 2), leading us to accept hypothesis $\mathrm{H}_{2}$. In other studies, over longer exposure periods, it has been observed that polyethylene $(<100 \mu \mathrm{m} ; 10$-day exposure) and LDPE microplastics (20-25 $\mu \mathrm{m}$; 28-day exposure) can significantly reduce granulocytehyalinocyte ratio in Mytilus sp. (Avio et al., 2015; Pittura et al., 2018). While not statistically significant, the marked increase in the proportion of granulocytes in response to microplastics observed here is curious. While it is thought that microplastics $<20 \mu \mathrm{m}$ can be translocated into the haemolymph of Mytilus sp. (Avio et al., 2015; Browne et al., 2008), it is not anticipated that the $20 \mu \mathrm{m}$ PS-MP or 10x30 
$\mu \mathrm{m}$ PA-MF used in these experiments would be able to enter the circulatory fluid. However, nanoparticles stemming from these microplastics certainly could translocate and incite an immune response. In Antarctic krill (Euphausia superba), amphipods (Gammarus duebeni) and shore crabs (Carcinus maenas), the gastric mill has been shown to physically damage microplastics resulting in the formation of nanoplastics (Dawson et al., 2018; Mateos-Cárdenas et al., 2020; Watts et al., 2015). We consider it plausible that mechanical grinding of PS-MP and PA-MF in the gastro-intestinal tract of mussels could also result in the formation of nanoplastics; we recommend this as an area for future consideration. Alternatively, inflammation resulting from abrasion or microplastic incursion into tissues could result in recruitment of granulocytes at a localised level.

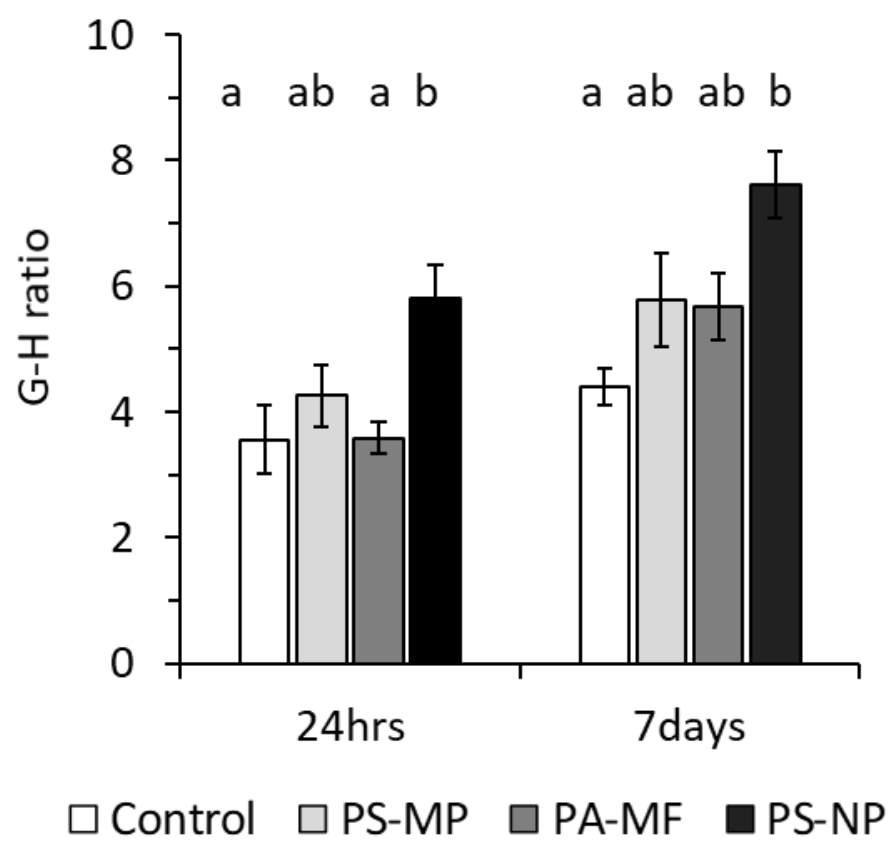

Figure 2. The Granulocyte-hyalinocyte ratio in mussel haemolymph; a biomarker of immune response (two-way ANOVA, treatment: $\mathrm{P}<0.05 ; \mathrm{n}=4$ ) following a $24 \mathrm{~h}$ and 7-day exposure to: controls (no plastic), $500 \mathrm{ng} \mathrm{mL}^{-1}$ polystyrene microbeads (PS-MP), $500 \mathrm{ng} \mathrm{mL}^{-1}$ polyamide microfibers (PA-MF) and $500 \mathrm{ng} \mathrm{mL} \mathrm{m}^{-1}$ polystyrene nanoparticles (PS-NP). Treatments that don't share letters are significantly different (Tukey post-hoc analysis).

\section{Oxidative balance: SOD and TBARS}

Superoxide dismutase (SOD) is an antioxidant enzyme that protects cells from toxic reactions with reactive oxygen species (ROS) and free radicals (e.g. $\mathrm{O}_{2}^{-}, \mathrm{OH}^{*}, \mathrm{HO}_{2}{ }^{*}$ ); prolonged increases in antioxidant activity can require energy that takes away from growth and reproduction (Trestrail et al., 2020). Here, SOD activity was significantly influenced by treatment in the gills (two-way ANOVA, 
treatment: $\mathrm{P}<0.05$; Figure $3 \mathrm{~A}$ ) being significantly increased in response to PS-NP in the $24 \mathrm{~h}$ exposure (Tukey, $\mathrm{P}<0.05$ ). SOD activity was also significantly influenced by treatment in the digestive gland (two -way ANOVA, treatment: $\mathrm{P}<0.05$; Figure $3 \mathrm{~B}$ ), with significantly higher SOD concentrations in PS-MP and PA-MF treatments in the $24 \mathrm{~h}$ exposure (Tukey, $\mathrm{P}<0.05$ ). After 7-days exposure, SOD concentrations were markedly reduced and not significantly different from the controls in either the gills (Tukey: $\mathrm{P}=0.2-1.0$; Figure $3 \mathrm{~A}$ ) or digestive glands (Tukey: $\mathrm{P}=0.4-0.9$; Figure $3 \mathrm{~B}$ ).

Other studies have also shown SOD activity to increase in the digestive glands and gills of Mytilus spp. exposed to 10-100 $\mu \mathrm{g} \mathrm{L}^{-1}$ PE-PP for 10 days (Revel et al., 2019), as well as the clam Scrobicularia plana following exposure to $1 \mathrm{mg} \mathrm{L}^{-1}$ PS-MP for 14 days (Ribeiro et al., 2017). Transcriptomic analyses of $M$. galloprovincialis exposed to HDPE for 18 days also showed an increased expression of genes related to immune and stress response in the digestive gland and mantle (Détrée and Gallardo-Escárate, 2018). However, Paul-Pont et al. (2016) observed no difference in SOD activity in Mytilus spp. following a 7-day exposure to PS-MP, and Magara et al. (2018) showed no effect on SOD activity in the gills or digestive glands of $M$. edulis exposed to $100-1000$ PE-MP mL ${ }^{-1}$ for 4 days. Wang et al. (2020) identified a non-significant increase in SOD activity in the digestive glands of the mussel Mytilus coruscus following $24 \mathrm{~h}$ exposure to microplastics, and no changes in SOD activity with longer exposure periods. 


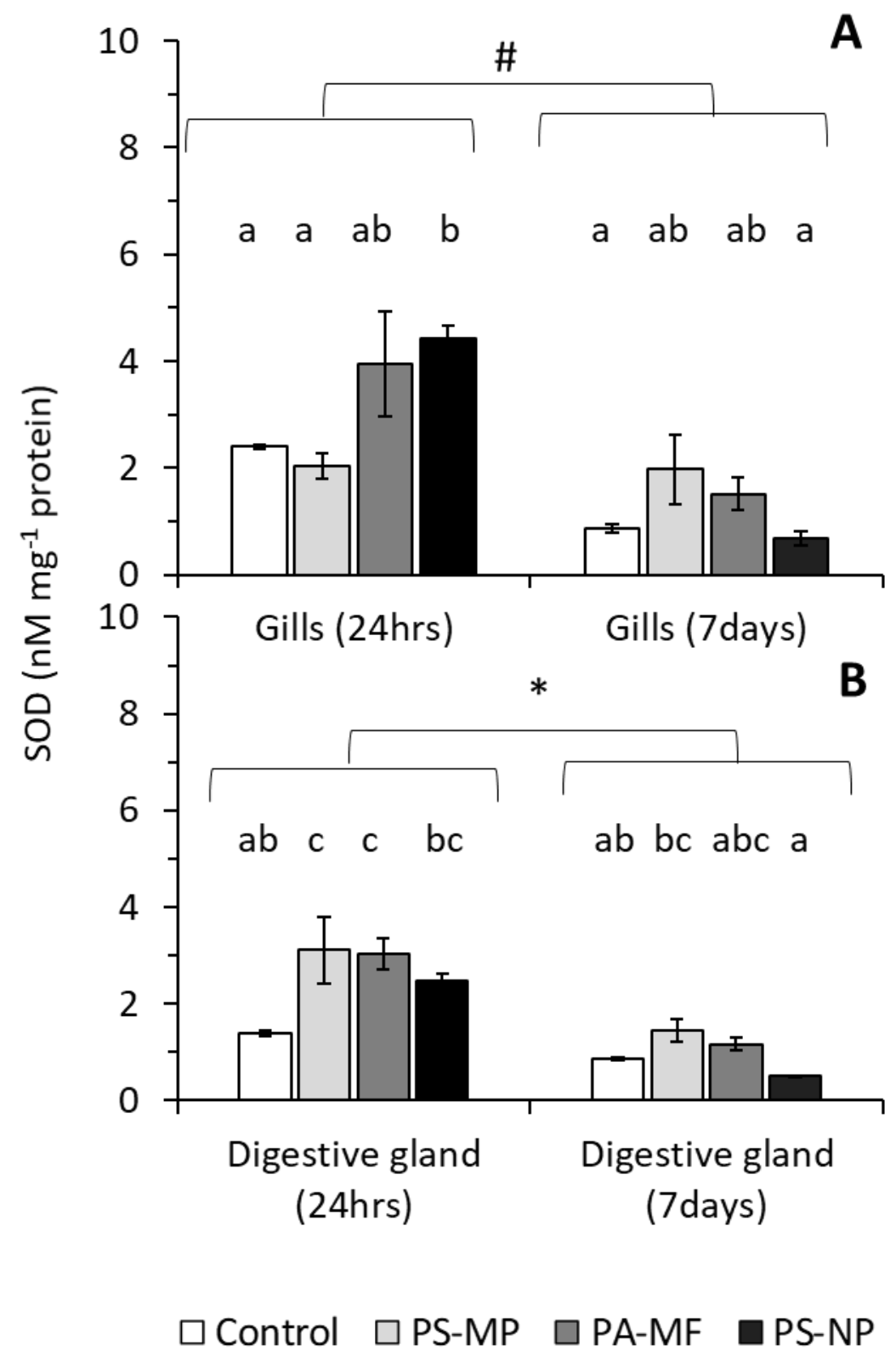

Figure 3. Superoxidase (SOD; $\mathrm{mg}^{-1}$ protein) activation in mussel tissues following $24 \mathrm{~h}$ and 7-day exposure to: controls (no plastic), $500 \mathrm{ng} \mathrm{mL}^{-1}$ polystyrene microbeads (PS-MP), $500 \mathrm{ng} \mathrm{mL}^{-1}$ polyamide microfibers (PA-MF) and $500 \mathrm{ng} \mathrm{mL}^{-1}$ polystyrene nanoparticles (PS-NP). (A) SOD activation in gills (two way-ANOVA, treatment: $P<0.05, n=4$ ). (B) SOD activation in digestive glands (two way-ANOVA, treatment: $P<0.05, n=4)$. Treatments that don't share letters are significantly different (Tukey posthoc analysis); \# denotes a statistical difference in the SOD response across treatments in gill tissue following $24 \mathrm{~h}$ and 7-day exposures (two-way ANOVA, treatment*time: $\mathrm{P}<0.05$ ); ${ }^{*}$ denotes statistical difference between SOD concentrations in digestive glands of mussels following $24 \mathrm{~h}$ and 7-day exposures (two-way ANOVA, time: $\mathrm{P}<0.05)$. 
Thiobarbituric acid reactive substances (TBARS) form as a byproduct of lipid peroxidation, stemming from the oxidative degradation of lipids by reactive oxygen species. TBARS concentrations in gill tissues were significantly affected by treatment (two-way ANOVA, treatment: $P<0.01$; Figure $4 \mathrm{~A}$ ), with significantly lower TBARS in the PS-NP exposure after $24 \mathrm{~h}$ exposure (Tukey, $\mathrm{P}<0.05$ ). We observed no difference in TBARS concentrations in the gills after 7-days exposure, nor the digestive glands after 24 h or 7-days exposure (two-way ANOVA, treatment: $\mathrm{P}=0.53$; Figure $4 \mathrm{~B}$ ). Further, there was no significant difference found between the $24 \mathrm{~h}$ and 7-day exposure data (two way-ANOVA, time: $\mathrm{P}=0.09$ (gills) and $\mathrm{P}=0.34$ (digestive glands)). Given no significant increases in TBARS concentrations were observed, our data would suggest no substitutive lipid peroxidation has occurred within our test models.

Our results differ from studies using plastic at concentrations a magnitude greater than used here; for example, Brandts et al. (2018a) demonstrated that exposure to PS-NP (0.05 $\mathrm{mg} \mathrm{L}^{-1}$ ) induced lipid peroxidation in the digestive glands of Mytilus galloprovincialis, and Oliveira et al. (2018) observed significant increases in TBARS in the freshwater bivalve Corbicula fluminea following exposure to 0.13 $\mathrm{mg} \mathrm{L}^{-1}$ of 1-5 $\mu \mathrm{m}$ microplastics. Notably Lei et al. (2018) observed substantial physical damage to intestinal epithelia, including removal of villi, in zebrafish (Danio rerio) exposed to microplastics (0.1$\left.5 \mu \mathrm{m} ; 1 \mathrm{mg} \mathrm{L}^{-1}\right)$. We posit that higher plastic concentrations may be sufficient to cause attrition within the gastro-intestinal tract resulting in the abrasion of tissues, leading to cellular damage and lipid peroxidation. 


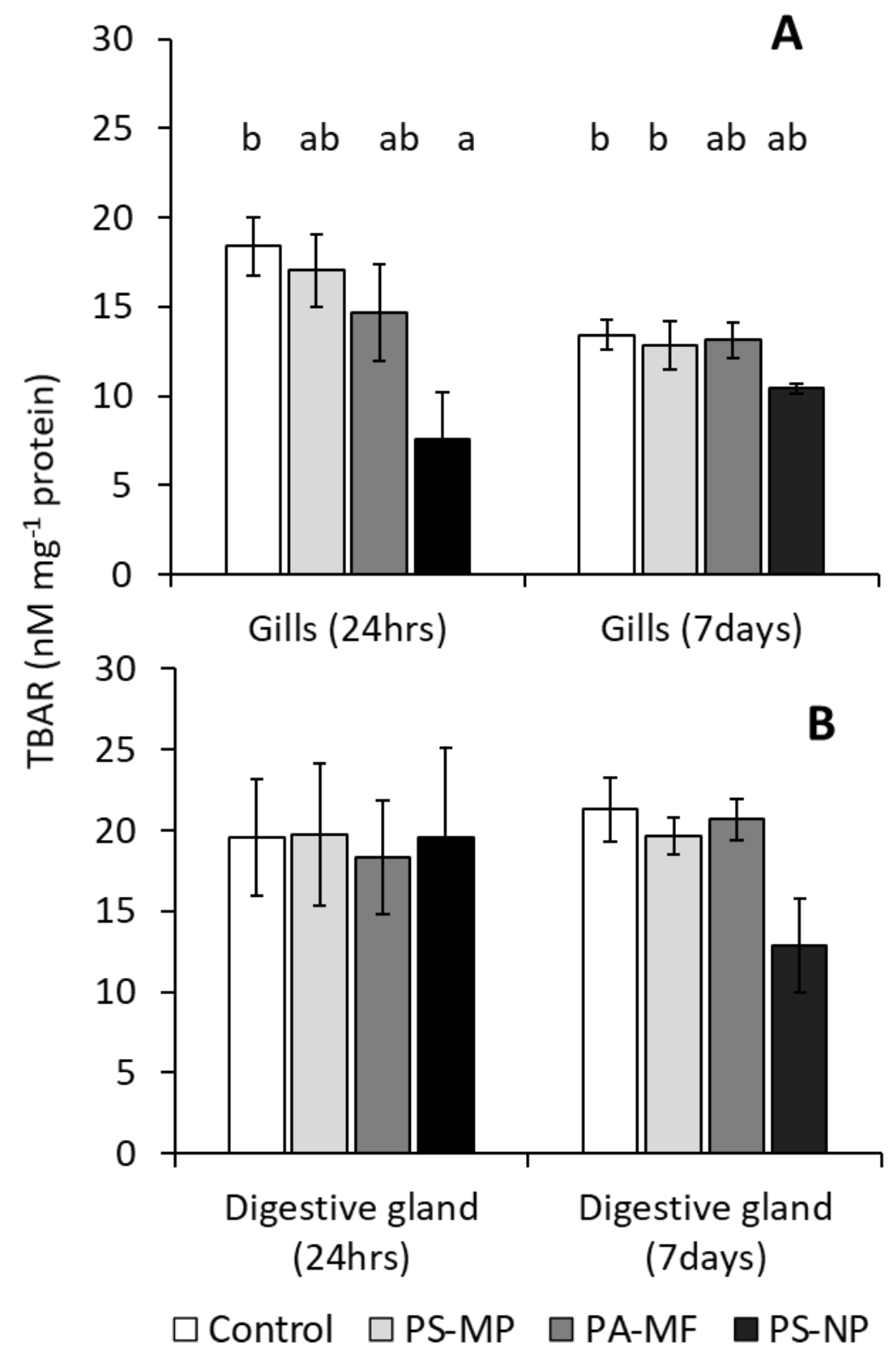

Figure 4. The response of Thiobarbituric acid reactive substances (TBARS, $\mathrm{nM} \mathrm{mg}^{-1}$ protein) in mussel tissues in mussels following $24 \mathrm{~h}$ and 7-day exposure to: controls (no plastic), $500 \mathrm{ng} \mathrm{mL}^{-1}$ polystyrene microbeads (PS-MP), $500 \mathrm{ng} \mathrm{mL}^{-1}$ polyamide microfibers (PA-MF) and $500 \mathrm{ng} \mathrm{mL}^{-1}$ polystyrene nanoparticles (PS-NP). (A) TBARS in gills (two-way ANOVA, Treatment: $P<0.05 ; n=4$ ) and (B) digestive glands (two-way ANOVA, Treatment: $\mathrm{P}=0.66, \mathrm{n}=4$ ). Treatments that don't share letters are significantly different (Tukey post-hoc analysis).

It is recognised that oxidative stress responses can be variable, differing with genotype, age, reproductive status, feeding and temperature, and that a broader suite of biomarkers and wider literature should be considered in inferring biological pathways (Magara et al., 2018; Trestrail et al., 
2020). Histological studies have shown that microplastics can permeate into the epithelial cells of the digestive gland resulting in epithelial thickening, the formation of granulocytomas and reduced epithelial cilia densities (Bråte et al., 2018; Paul-Pont et al., 2016; von Moos et al., 2012). This localised inflammation can stem from release of ROS and impaired intracellular homeostasis, and has been widely evidenced in tissues exposed to nanoparticles in vivo and in vitro (Chaudhari et al., 2014; Khanna et al., 2015; Manke et al., 2013; Rosen et al., 1995). In assessing the response of the copepod Paracyclopina nana to 0.05 and $0.5 \mu \mathrm{m}$ PS-MP, Jeong et al. (2017) drew similar conclusions, hypothesising prolonged cellular exposure to microplastics elevated intracellular ROS levels, triggering the activation of antioxidant genes. In this study, the increase in SOD activity after $24 \mathrm{~h}$ would indicate micro- and nanoplastics triggered an oxidative challenge; but given SOD activity was normal after 7days exposure, we can infer this oxidative challenge was short-lived and would therefore not have been energetically taxing (Trestrail et al., 2020).

\section{Lysosomal destabilisation: Neutral red retention}

Lysosomes are membrane bound organelles, containing hydrolytic enzymes maintained at a low $\mathrm{pH}$, with the function of removing endogenous and extraneous waste from the cell ( $X u$ and Ren, 2015). Lysosomal membrane stability can be disrupted by environmental stressors (e.g. pollution, hypoxia), reducing their capacity to retain the tracer neutral red (Petrović et al., 2001). Our neutral red retention data showed that a 7-day exposure to plastic particulates at $500 \mathrm{ng} \mathrm{mL}^{-1}$ had no impact on lysosomal stability (Kruskal-Wallis, $\mathrm{P}=0.63$; Figure 5 ).

This concurs with other recent studies. For example, in the Eastern oyster (Crassostrea virginica) $4 \mathrm{~h}$ in vitro and $48 \mathrm{~h}$ in vivo exposures to $3 \mu \mathrm{m}$ PS-MP and $50 \mathrm{~nm}$ PS-NP (100 ppb) had no effect on lysosome stability, despite microscopic evidence for PS-NP accumulation within lysosomes via endocytic pathways (Gaspar et al., 2018). Further, no impact on lysosomal stability was observed in M. galloprovincialis exposed to LDPE microplastics for 7-28 days, as measured using the NRRT assay (Pittura et al., 2018). Conversely, in M. edulis, epithelial uptake of HDPE was linked with reduced lysosomal membrane stability (von Moos et al., 2012), and a 10-day exposure to PS-MP resulted in decreased lysosome membrane stability of M. galloprovincialis haemocytes (Avio et al., 2015). 


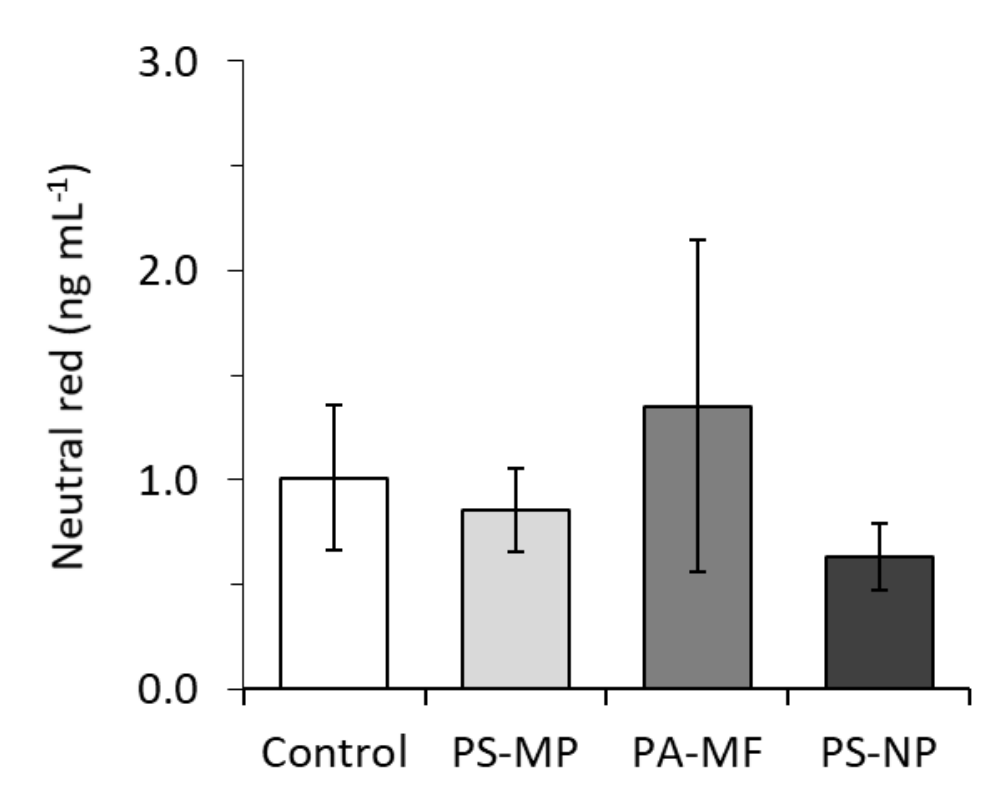

Figure 5. The response of Neutral red retention (ng neutral red retained per $\mathrm{mL}$ of haemolymph); a biomarker of lysosomal stability in mussel haemocytes (Kruskal-Wallis, $P=0.63 ; n=3$ ), following a 7-day exposure to: controls (no plastic), $500 \mathrm{ng} \mathrm{mL}^{-1}$ polystyrene microbeads (PS-MP), $500 \mathrm{ng} \mathrm{mL}^{-1}$ polyamide microfibers (PA-MF) and $500 \mathrm{ng} \mathrm{mL}^{-1}$ polystyrene nanoparticles (PS-NP).

\section{Genotoxicity: Micronucleus and comet assays}

The results of the micronucleus and comet assays showed that the micro- and nanoplastics used in these exposures did not cause significant genotoxic damage to $M$. edulis following $24 \mathrm{~h}$ or 7 -day exposures. However, we did observe a significant increase in the number of micronuclei per one thousand cells between exposures (two-way ANOVA, time: $\mathrm{P}>0.05$ ). Following exposures, an average of 1-1.5 micronuclei per 1000 cells were identified in the control treatment, with notably greater micronuclei abundance following plastic exposure, although such increases were not significant (ANOVA, treatment: $\mathrm{P}=0.33$; Figure $6 \mathrm{~A}$ ). Similarly others found, a 21-day exposure to virgin and weathered polyethylene granules (50-600 $\mu \mathrm{m})$, a 7-28 day exposure to LDPE microplastics (20-25 $\mu \mathrm{m})$ and a 10-day exposure to PE or PS microplastics $(<100 \mu \mathrm{m})$ had no effect on micronuclei formation in the haemocytes of M. galloprovincialis (Avio et al., 2015; Bråte et al., 2018; Pittura et al., 2018).

In the control treatment, cells showed a baseline average of 5.2\% DNA damage (i.e. proportion of fragmented DNA in the "comet tail": single strand breaks), which is well within normal parameters (Mitchelmore et al., 1998). It was observed that DNA damage did not differ significantly between controls and other treatments (Binomial GLM; PS-MP, P=0.86; PA-MF, P=0.90; PS-NP, $\mathrm{P}=0.82$; Figure 6B). However, Revel et al. (2019) did observe a significant increase in haemocytic DNA damage in 
mussels exposed to $>10 \mu \mathrm{g} \mathrm{L}^{-1}$ of PE-PP microplastics after a 10-day exposure (potentially stemming from nanoplastics in the sample), while Brandts et al. (2018a) showed significantly increased DNA damage in the haemocytes of M. galloprovincialis exposed to PS-NP for $96 \mathrm{~h}$. Genotoxic damage could stem from physical-interactions between cell nuclei and nanoparticles, the leaching of toxic chemicals present within different plastics or high concentrations of reactive oxygen species, but in these two studies the underlying mechanisms could not be isolated.
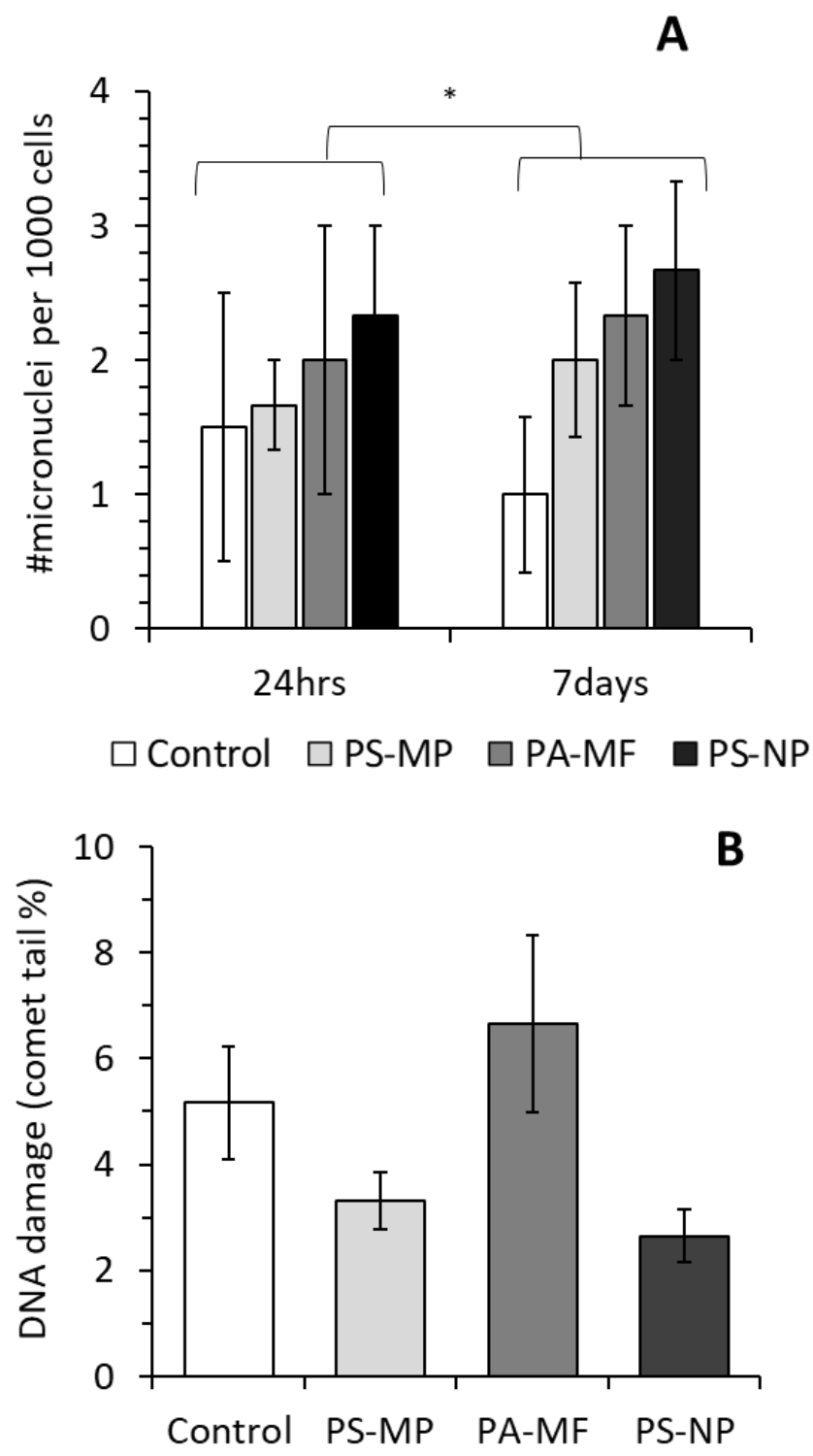

Figure 6. The response of genotoxicity biomarkers in mussels, following exposure to: controls (no plastic), $500 \mathrm{ng} \mathrm{mL}^{-1}$ polystyrene microbeads (PS-MP), $500 \mathrm{ng} \mathrm{mL}^{-1}$ polyamide microfibers (PA-MF) and $500 \mathrm{ng} \mathrm{mL}^{-1}$ polystyrene nanoparticles (PS-NP). (A) Number of micronuclei per 1000 haemocytes from $24 \mathrm{~h}$ and 7-day exposures (two-way ANOVA, treat=P<0.05, $\mathrm{n}=4$ ). (B) DNA damage (measured as percentage of DNA in comet tail) (ANOVA, treat $=P<0.05, n=8$ ). Treatments that don't share letters are 
significantly different (Tukey post-hoc analysis). * denotes statistical difference between micronuclei per 1000 haemocytes in mussels between 24-h and 7-day exposures (two-way ANOVA, time=P<0.05).

\section{Conclusions}

In this study we explored how the shape and size of plastic particulates might affect their toxicity in the model organism Mytilus spp. Exposure to microplastics, microfibres and nanoplastics $(500 \mathrm{ng} \mathrm{mL}$ ${ }^{1}$ ) resulted in significantly higher SOD activity after $24 \mathrm{~h}$ exposure; after 7-days exposure, SOD activity has returned to normal values, indicating the oxidative challenge was short-lived and therefore would be unlikely to result in adverse health effects. We did not observe any significant difference in the sublethal toxicity of microfibres and microplastic beads of similar equivalent spherical diameter, leading to a rejection of our hypothesis that particle aspect-ratio would influence toxicity. However, our results did indicate that particle size influences sub-lethal toxicity, as nanoplastic exposure increased the proportion of phagocytic haemocytes (indicative of a heightened immune response) and resulted in a marked increase in micronuclei formation. We postulate nanoscopic plastics can more readily permeate into the circulatory fluid and tissues inciting an immune response and causing cytotoxicity. We recommend further research is required to consider if: (1) prolonged exposure to plastic results in a sustained heightened immune response; (2) passage through the intestinal tract causes microplastics to abrade into nanoplastics; (3) changes in ecophysiology and apical endpoints (growth, reproduction, mortality) can be observed from chronic exposures using both juvenile and adult life stages.

\section{Acknowledgements}

This research was financially supported by the UK Natural Environmental Research Council (NE/L007010, NE/L003988 and NE/N006178). GC and CD were funded by the Campus World and ERASMUS programme respectively. MC and PL acknowledge funding from the Waitrose Plastic Plan Fund. Thank you to Dr Seta Noventa and Darren Rowe for assistance with the experimental work. Our thanks to the anonymous reviewers who provided valuable feedback.

\section{References}

Au, S.Y., Bruce, T.F., Bridges, W.C., Klaine, S.J., 2015. Responses of Hyalella azteca to acute and chronic microplastic. Environmental Toxicology and Chemistry 34, 2564-2572.

Avio, C.G., Gorbi, S., Milan, M., Benedetti, M., Fattorini, D., d'Errico, G., Pauletto, M., Bargelloni, L., Regoli, F., 2015. Pollutants bioavailability and toxicological risk from microplastics to marine mussels. Environmental Pollution 198, 211-222.

Beninger, P., St-Jean, S., Poussart, Y., 1995. Labial palps of the blue mussel Mytilus edulis (Bivalvia: Mytilidae). Marine Biology 123, 293-303. 
Bergmann, M., Peeken, I., Beyer, B., Krumpen, T., Primpke, S., Tekman, M., Gerdts, G., 2016. Vast quantities of microplastics in Arctic Sea Ice-a prime temporary sink for plastic litter and a medium of transport. Fate and impact of microplastics in marine ecosystems, 75-76.

Besseling, E., Wang, B., Lürling, M., Koelmans, A.A., 2014. Nanoplastic affects growth of S. obliquus and reproduction of D. magna. Environmental science \& technology 48, 12336-12343.

Besseling, E., Wegner, A., Foekema, E.M., van den Heuvel-Greve, M.J., Koelmans, A.A., 2013. Effects of Microplastic on Fitness and PCB Bioaccumulation by the Lugworm Arenicola marina (L.). Environmental Science \& Technology 47, 593-600.

Bradford, M.M., 1976. A rapid and sensitive method for the quantitation of microgram quantities of protein utilizing the principle of protein-dye binding. Analytical biochemistry 72, 248-254.

Brandts, I., Teles, M., Gonçalves, A., Barreto, A., Franco-Martinez, L., Tvarijonaviciute, A., Martins, M., Soares, A., Tort, L., Oliveira, M., 2018a. Effects of nanoplastics on Mytilus galloprovincialis after individual and combined exposure with carbamazepine. Science of The Total Environment 643, 775784.

Brandts, I., Teles, M., Tvarijonaviciute, A., Pereira, M., Martins, M., Tort, L., Oliveira, M., 2018b. Effects of polymethylmethacrylate nanoplastics on Dicentrarchus labrax. Genomics 110, 435-441.

Bråte, I.L.N., Blázquez, M., Brooks, S.J., Thomas, K.V., 2018. Weathering impacts the uptake of polyethylene microparticles from toothpaste in Mediterranean mussels (M. galloprovincialis). Science of the Total Environment 626, 1310-1318.

Browne, M.A., Dissanayake, A., Galloway, T.S., Lowe, D.M., Thompson, R.C., 2008. Ingested Microscopic Plastic Translocates to the Circulatory System of the Mussel, Mytilus edulis (L.). Environmental Science \& Technology 42, 5026-5031.

Buege, J.A., Aust, S.D., 1978. [30] Microsomal lipid peroxidation, Methods in enzymology. Elsevier, pp. 302-310.

Catarino, A.I., Frutos, A., Henry, T.B., 2019. Use of fluorescent-labelled nanoplastics (NPs) to demonstrate NP absorption is inconclusive without adequate controls. Science of The Total Environment.

Chaudhari, N., Talwar, P., Parimisetty, A., Lefebvre d'Hellencourt, C., Ravanan, P., 2014. A molecular web: endoplasmic reticulum stress, inflammation, and oxidative stress. Frontiers in cellular neuroscience 8, 213.

Cole, M., 2016. Novel method for preparing microplastic fibres. Scientific Reports.

Cole, M., Coppock, R., Lindeque, P.K., Altin, D., Reed, S., Pond, D.W., Sørensen, L., Galloway, T.S., Booth, A.M., 2019. Effects of Nylon Microplastic on Feeding, Lipid Accumulation, and Moulting in a Coldwater Copepod. Environmental science \& technology.

Cole, M., Galloway, T., 2015. Ingestion of nanoplastics and microplastics by Pacific oyster larvae. Environmental Science \& Technology 49, 14625-14632.

Cole, M., Lindeque, P., Fileman, E., Halsband, C., Galloway, T., 2015. The impact of polystyrene microplastics on feeding, function and fecundity in the marine copepod Calanus helgolandicus. Environmental Science \& Technology 49, 1130-1137.

Cole, M., Lindeque, P., Halsband, C., Galloway, T.S., 2011. Microplastics as contaminants in the marine environment: A review. Marine Pollution Bulletin 62, 2588-2597.

Coppock, R.L., Galloway, T.S., Cole, M., Fileman, E.S., Queiros, A.M., Lindeque, P.K., 2019. Microplastics alter feeding selectivity and faecal density in the copepod, Calanus helgolandicus. Science of The Total Environment.

Dawson, A.L., Kawaguchi, S., King, C.K., Townsend, K.A., King, R., Huston, W.M., Nash, S.M.B., 2018. Turning microplastics into nanoplastics through digestive fragmentation by Antarctic krill. Nature communications 9, 1001.

De Witte, B., Devriese, L., Bekaert, K., Hoffman, S., Vandermeersch, G., Cooreman, K., Robbens, J., 2014. Quality assessment of the blue mussel (Mytilus edulis): Comparison between commercial and wild types. Marine Pollution Bulletin 85, 146-155. 
Détrée, C., Gallardo-Escárate, C., 2018. Single and repetitive microplastics exposures induce immune system modulation and homeostasis alteration in the edible mussel Mytilus galloprovincialis. Fish \& shellfish immunology 83, 52-60.

Faggio, C., Tsarpali, V., Dailianis, S., 2018. Mussel digestive gland as a model tissue for assessing xenobiotics: an overview. Science of the Total Environment 636, 220-229.

Farrington, J.W., Tripp, B.W., Tanabe, S., Subramanian, A., Sericano, J.L., Wade, T.L., Knap, A.H., 2016. Edward D. Goldberg's proposal of "the Mussel Watch": Reflections after 40 years. Marine Pollution Bulletin 110, 501-510.

Galloway, T.S., Cole, M., Lewis, C., 2017. Interactions of microplastic debris throughout the marine ecosystem. Nature Ecology \& Evolution 1, s41559-41017-40116.

Gaspar, T.R., Chi, R.J., Parrow, M.W., Ringwood, A.H., 2018. Cellular bioreactivity of micro-and nanoplastic particles in oysters. Frontiers in Marine Science 5, 345.

Gorbi, S., Avio, G., Benedetti, M., Totti, C., Accoroni, S., Pichierri, S., Bacchiocchi, S., Orletti, R., Graziosi, T., Regoli, F., 2013. Effects of harmful dinoflagellate Ostreopsis cf. ovata exposure on immunological, histological and oxidative responses of mussels Mytilus galloprovincialis. Fish \& shellfish immunology 35, 941-950.

Gosling, E., 2003. Bivalve molluscs. Wiley Online Library.

Gray, A.D., Weinstein, J.E., 2017. Size-and shape-dependent effects of microplastic particles on adult daggerblade grass shrimp (Palaemonetes pugio). Environmental toxicology and chemistry 36, 30743080.

Greven, A.C., Merk, T., Karagöz, F., Mohr, K., Klapper, M., Jovanović, B., Palić, D., 2016. Polycarbonate and polystyrene nanoplastic particles act as stressors to the innate immune system of fathead minnow (Pimephales promelas). Environmental toxicology and chemistry 35, 3093-3100.

Gustafson, H.H., Holt-Casper, D., Grainger, D.W., Ghandehari, H., 2015. Nanoparticle uptake: the phagocyte problem. Nano today 10, 487-510.

Hartmann, N.B., Hüffer, T., Thompson, R., Hassellöv, M., Verschoor, A., Daugaard, A., Rist, S., Karlsson, T.M., Brennholt, N., Cole, M., Herrling, M., Heß, M., Ivleva, N., Lusher, A., Wagner, M., 2019. Are we speaking the same language? Recommendations for a definition and categorization framework for plastic debris. Environmental Science \& Technology 53, 1039-1047.

Hu, W., Culloty, S., Darmody, G., Lynch, S., Davenport, J., Ramirez-Garcia, S., Dawson, K., Lynch, I., Doyle, H., Sheehan, D., 2015. Neutral red retention time assay in determination of toxicity of nanoparticles. Marine environmental research 111, 158-161.

Hussain, N., 2001. Fluorometric method for the simultaneous quantitation of differently-sized nanoparticles in rodent tissue. International journal of pharmaceutics 214, 55-61.

Jeong, C.-B., Kang, H.-M., Lee, M.-C., Kim, D.-H., Han, J., Hwang, D.-S., Souissi, S., Lee, S.-J., Shin, K.-H., Park, H.G., 2017. Adverse effects of microplastics and oxidative stress-induced MAPK/Nrf2 pathwaymediated defense mechanisms in the marine copepod Paracyclopina nana. Scientific reports 7, 1-11. Jha, A.N., 2008. Ecotoxicological applications and significance of the comet assay. Mutagenesis 23, 207-221.

Kach, D.J., Ward, J.E., 2008. The role of marine aggregates in the ingestion of picoplankton-size particles by suspension-feeding molluscs. Marine Biology 153, 797-805.

Khanna, P., Ong, C., Bay, B.H., Baeg, G.H., 2015. Nanotoxicity: an interplay of oxidative stress, inflammation and cell death. Nanomaterials 5, 1163-1180.

Kolandhasamy, P., Su, L., Li, J., Qu, X., Jabeen, K., Shi, H., 2018. Adherence of microplastics to soft tissue of mussels: a novel way to uptake microplastics beyond ingestion. Science of the Total Environment 610, 635-640.

Koukouzika, N., Raftopoulou, E., Dimitriadis, V., 2009. Seasonal differences of lysosomal, lipid and lipofuscin parameters in the digestive gland of the mussel Mytilus galloprovincialis. Journal of Molluscan Studies 75, 261-267. 
Lei, L., Wu, S., Lu, S., Liu, M., Song, Y., Fu, Z., Shi, H., Raley-Susman, K.M., He, D., 2018. Microplastic particles cause intestinal damage and other adverse effects in zebrafish Danio rerio and nematode Caenorhabditis elegans. Science of the Total Environment 619, 1-8.

Lenz, R., Enders, K., Nielsen, T.G., 2016. Microplastic exposure studies should be environmentally realistic. Proceedings of the National Academy of Sciences 113, E4121-E4122.

Lewis, C., Galloway, T., 2009. Reproductive consequences of paternal genotoxin exposure in marine invertebrates. Environmental science \& technology 43, 928-933.

Li, J., Green, C., Reynolds, A., Shi, H., Rotchell, J.M., 2018. Microplastics in mussels sampled from coastal waters and supermarkets in the United Kingdom. Environmental Pollution 241, 35-44.

Li, J., Yang, D., Li, L., Jabeen, K., Shi, H., 2015. Microplastics in commercial bivalves from China. Environmental Pollution 207, 190-195.

Lindeque, P.K., Cole, M., Coppock, R.L., Lewis, C.N., Miller, R.Z., Watts, A.J.R., Wilson-McNeal, A., Wright, S.L., Galloway, T.S., 2020. Are we underestimating microplastic abundance in the marine environment? A comparison of microplastic capture with nets of different mesh-size. Environmental Pollution, 114721.

Lowe, D.M., Moore, M.N., 1979. The cytology and occurrence of granulocytomas in mussels. Marine pollution bulletin 10, 137-141.

Lu, Y., Zhang, Y., Deng, Y., Jiang, W., Zhao, Y., Geng, J., Ding, L., Ren, H., 2016. Uptake and accumulation of polystyrene microplastics in zebrafish (Danio rerio) and toxic effects in liver. Environmental science \& technology 50, 4054-4060.

Lusher, A., 2015. Microplastics in the marine environment: distribution, interactions and effects, in: Bergmann, M., Gutow, L., Klages, M. (Eds.), Marine Anthropogenic Litter. Springer, pp. 245-307.

Magara, G., Elia, A.C., Syberg, K., Khan, F.R., 2018. Single contaminant and combined exposures of polyethylene microplastics and fluoranthene: accumulation and oxidative stress response in the blue mussel, Mytilus edulis. Journal of Toxicology and Environmental Health, Part A 81, 761-773.

Malvern, 2014. Basic principles of particle size analysis, Application Note. Malvern Instruments Limited.

Manke, A., Wang, L., Rojanasakul, Y., 2013. Mechanisms of nanoparticle-induced oxidative stress and toxicity. BioMed research international 2013.

Mateos-Cárdenas, A., O'Halloran, J., van Pelt, F.N., Jansen, M.A., 2020. Rapid fragmentation of microplastics by the freshwater amphipod Gammarus duebeni (Lillj.). Scientific Reports 10, 1-12.

Mishra, S., charan Rath, C., Das, A.P., 2019. Marine microfiber pollution: a review on present status and future challenges. Marine pollution bulletin 140, 188-197.

Mitchelmore, C.L., Birmelin, C., Livingstone, D.R., Chipman, J.K., 1998. Detection of DNA Strand Breaks in Isolated Mussel (Mytilus edulisL.) Digestive Gland Cells Using the "Comet" Assay. Ecotoxicology and Environmental Safety 41, 51-58.

Noventa, S., Rowe, D., Galloway, T., 2018. Mitigating effect of organic matter on the in vivo toxicity of metal oxide nanoparticles in the marine environment. Environmental Science: Nano 5, 1764-1777.

Oliveira, P., Barboza, L.G.A., Branco, V., Figueiredo, N., Carvalho, C., Guilhermino, L., 2018. Effects of microplastics and mercury in the freshwater bivalve Corbicula fluminea (Müller, 1774): Filtration rate, biochemical biomarkers and mercury bioconcentration. Ecotoxicology and environmental safety 164, 155-163.

Paul-Pont, I., Lacroix, C., Fernández, C.G., Hégaret, H., Lambert, C., Le Goïc, N., Frère, L., Cassone, A.L., Sussarellu, R., Fabioux, C., 2016. Exposure of marine mussels Mytilus spp. to polystyrene microplastics: toxicity and influence on fluoranthene bioaccumulation. Environmental pollution 216, 724-737.

Petrović, S., Ozretić, B., Krajnović-Ozretić, M., Bobinac, D., 2001. Lysosomal membrane stability and metallothioneins in digestive gland of mussels (Mytilus galloprovincialis Lam.) as biomarkers in a field study. Marine Pollution Bulletin 42, 1373-1378.

Pittura, L., Avio, C.G., Giuliani, M.E., d'Errico, G., Keiter, S.H., Cormier, B., Gorbi, S., Regoli, F., 2018. Microplastics as vehicles of environmental PAHs to marine organisms: combined chemical and 
physical hazards to the Mediterranean mussels, Mytilus galloprovincialis. Frontiers in Marine Science 5, 103.

Porter, A., Lyons, B.P., Galloway, T.S., Lewis, C.N., 2018. The role of marine snows in microplastic fate and bioavailability. Environmental science \& technology 52, 7111-7119.

$R$, 2019. R: A language and environment for statistical computing. , $R$ Foundation for Statistical Computing, 3.6.0 ed, Vienna, Austria.

Ravnic, D.J., Zhang, Y.-Z., Tsuda, A., Pratt, J.P., Huss, H.T., Mentzer, S.J., 2006. Multi-image particle tracking velocimetry of the microcirculation using fluorescent nanoparticles. Microvascular research 72, 27-33.

Repetto, G., Del Peso, A., Zurita, J.L., 2008. Neutral red uptake assay for the estimation of cell viability/cytotoxicity. Nature protocols 3, 1125.

Revel, M., Lagarde, F., Perrein-Ettajani, H., Bruneau, M., Akcha, F., Sussarellu, R., Rouxel, J., Costil, K., Decottignies, P., Cognie, B., 2019. Tissue-specific biomarker responses in the blue mussel Mytilus spp. exposed to a mixture of microplastics at environmentally relevant concentrations. Frontiers in Environmental Science 7, 33.

Ribeiro, F., Garcia, A.R., Pereira, B.P., Fonseca, M., Mestre, N.C., Fonseca, T.G., Ilharco, L.M., Bebianno, M.J., 2017. Microplastics effects in Scrobicularia plana. Marine pollution bulletin 122, 379-391.

Rist, S., Baun, A., Hartmann, N.B., 2017. Ingestion of micro-and nanoplastics in Daphnia magnaQuantification of body burdens and assessment of feeding rates and reproduction. Environmental Pollution 228, 398-407.

Rochman, C.M., Tahir, A., Williams, S.L., Baxa, D.V., Lam, R., Miller, J.T., Teh, F.-C., Werorilangi, S., Teh, S.J., 2015. Anthropogenic debris in seafood: Plastic debris and fibers from textiles in fish and bivalves sold for human consumption. Scientific Reports 5.

Rosa, M., Ward, J.E., Shumway, S.E., 2018. Selective Capture and Ingestion of Particles by SuspensionFeeding Bivalve Molluscs: A Review. Journal of Shellfish Research 37, 727-747.

Rosen, G.M., Pou, S., Ramos, C.L., Cohen, M.S., Britigan, B.E., 1995. Free radicals and phagocytic cells. The FASEB Journal 9, 200-209.

Saavedra, J., Stoll, S., Slaveykova, V.I., 2019. Influence of nanoplastic surface charge on eco-corona formation, aggregation and toxicity to freshwater zooplankton. Environmental pollution 252, 715-722. Santana, M., Ascer, L., Custódio, M., Moreira, F., Turra, A., 2016. Microplastic contamination in natural mussel beds from a Brazilian urbanized coastal region: Rapid evaluation through bioassessment. Marine pollution bulletin 106, 183-189.

Sendra, M., Saco, A., Yeste, M.P., Romero, A., Novoa, B., Figueras, A., 2019. Nanoplastics: From tissue accumulation to cell translocation into Mytilus galloprovincialis hemocytes. resilience of immune cells exposed to nanoplastics and nanoplastics plus Vibrio splendidus combination. Journal of Hazardous Materials, 121788.

Setälä, O., Lehtiniemi, M., Coppock, R., Cole, M., 2018. Microplastics in marine food webs, Microplastic contamination in aquatic environments. Elsevier, pp. 339-363.

Stephenson, K., Thomas, O., 2019. Exe Estuary - Mussel Stock Assessment 2018. IFCA.

Sussarellu, R., Suquet, M., Thomas, Y., Lambert, C., Fabioux, C., Pernet, M.E.J., Le Goïc, N., Quillien, V., Mingant, C., Epelboin, Y., 2016. Oyster reproduction is affected by exposure to polystyrene microplastics. Proceedings of the National Academy of Sciences 113, 2430-2435.

Tallec, K., Huvet, A., Di Poi, C., González-Fernández, C., Lambert, C., Petton, B., Le Goïc, N., Berchel, M., Soudant, P., Paul-Pont, I., 2018. Nanoplastics impaired oyster free living stages, gametes and embryos. Environmental pollution 242, 1226-1235.

Ter Halle, A., Jeanneau, L., Martignac, M., Jardé, E., Pedrono, B., Brach, L., Gigault, J., 2017. Nanoplastic in the North Atlantic subtropical gyre. Environmental science \& technology 51, 13689-13697.

Trestrail, C., Nugegoda, D., Shimeta, J., 2020. Invertebrate responses to microplastic ingestion: Reviewing the role of the antioxidant system. Science of The Total Environment, 138559.

Van Cauwenberghe, L., Janssen, C.R., 2014. Microplastics in bivalves cultured for human consumption. Environmental Pollution 193, 65-70. 
Viarengo, A., Canesi, L., 1991. Mussels as biological indicators of pollution. Aquaculture 94, 225-243. von Moos, N., Burkhardt-Holm, P., Köhler, A., 2012. Uptake and effects of microplastics on cells and tissue of the blue mussel Mytilus edulis L. after an experimental exposure. Environmental science \& technology 46, 11327-11335.

Walkinshaw, C., Lindeque, P.K., Thompson, R., Tolhurst, T., Cole, M., 2020. Microplastics and seafood: lower trophic organisms at highest risk of contamination. Ecotoxicology and Environmental Safety 190, 110066.

Wang, X., Huang, W., Wei, S., Shang, Y., Gu, H., Wu, F., Lan, Z., Hu, M., Shi, H., Wang, Y., 2020. Microplastics impair digestive performance but show little effects on antioxidant activity in mussels under low pH conditions. Environmental Pollution 258, 113691.

Ward, J., Targett, N., 1989. Influence of marine microalgal metabolites on the feeding behavior of the blue mussel Mytilus edulis. Marine Biology 101, 313-321.

Ward, J.E., Rosa, M., Shumway, S.E., 2019a. Capture, ingestion, and egestion of microplastics by suspension-feeding bivalves: a 40-year history. Anthropocene Coasts 2, 39-49.

Ward, J.E., Shumway, S.E., 2004. Separating the grain from the chaff: particle selection in suspensionand deposit-feeding bivalves. Journal of Experimental Marine Biology and Ecology 300, 83-130.

Ward, J.E., Zhao, S., Holohan, B., Mladinich, K.M., Griffin, T.W., Wozniak, J., Shumway, S.E., 2019b. Selective ingestion and egestion of plastic particles by the blue mussel (Mytilus edulis) and eastern oyster (Crassostrea virginica): implications for using bivalves as bioindicators of microplastic pollution. Environmental science \& technology 53, 8776-8784.

Watts, A.J.R., Urbina, M.A., Corr, S., Lewis, C., Galloway, T.S., 2015. Ingestion of plastic microfibers by the crab Carcinus maenas and its effect on food consumption and energy balance. Environmental Science \& Technology 49, 14597-14604.

Wegner, A., Besseling, E., Foekema, E., Kamermans, P., Koelmans, A., 2012. Effects of nanopolystyrene on the feeding behavior of the blue mussel (Mytilus edulis L.). Environmental Toxicology and Chemistry 31, 2490-2497.

Woods, M.N., Stack, M.E., Fields, D.M., Shaw, S.D., Matrai, P.A., 2018. Microplastic fiber uptake, ingestion, and egestion rates in the blue mussel (Mytilus edulis). Marine pollution bulletin 137, 638645.

Wright, S., Rowe, D., Thompson, R.C., Galloway, T.S., 2013. Microplastic ingestion decreases energy reserves in marine worms. Current Biology 23, 1031-1033.

Wright, S.L., Rowe, D., Reid, M.J., Thomas, K.V., Galloway, T.S., 2015. Bioaccumulation and biological effects of cigarette litter in marine worms. Scientific Reports 5.

Xu, H., Ren, D., 2015. Lysosomal physiology. Annual review of physiology 77, 57-80.

Zhao, S., Ward, J.E., Danley, M., Mincer, T.J., 2018. Field-based evidence for microplastic in marine aggregates and mussels: implications for trophic transfer. Environmental science \& technology 52, 11038-11048. 